WHY CONTROL IMMIGRATION? 
This page intentionally left blank 
CARESS SCHENK

\section{Why Control Immigration?}

Strategic Uses of Migration Management in Russia

UNIVERSITY OF TORONTO PRESS

Toronto Buffalo London 
(C) University of Toronto Press 2018

Toronto Buffalo London

utorontopress.com

Printed in the U.S.A.

ISBN 978-1-4875-0297-3

(2) Printed on acid-free, $100 \%$ post-consumer recycled paper with vegetable-based inks.

\section{Library and Archives Canada Cataloguing in Publication}

Schenk, Caress, 1977-, author

Why control immigration? : strategic uses of migration management in Russia / Caress Schenk.

Includes bibliographical references and index. ISBN 978-1-4875-0297-3 (hardcover)

1. Russia (Federation)-Emigration and immigration-Government policy. 2. Immigrants-Government policy-Russia (Federation). I. Title.

JV8190.S34 $2018 \quad 325.47 \quad$ C2017-906081-3

Publication of this book was made possible, in part, by a grant from the First Book Subvention Program of the Association for Slavic, East European, and Eurasian Studies.

University of Toronto Press acknowledges the financial assistance to its publishing program of the Canada Council for the Arts and the Ontario Arts Council, an agency of the Government of Ontario.

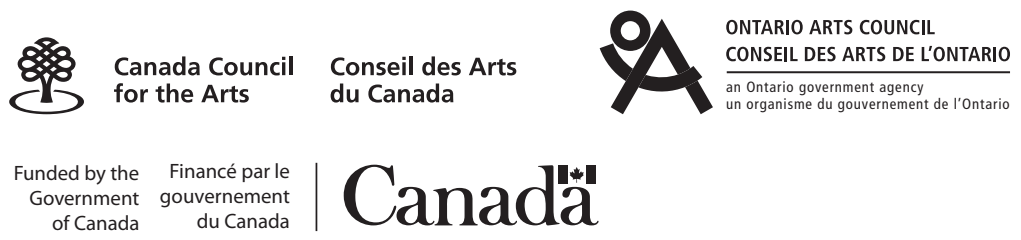


To Brian, Malcolm, August, and Eloise, my little tribe of misfits and co-adventurers, who keep everything in perspective for me. 
This page intentionally left blank 